\title{
Epigenetic silencing of IGFBPL1 promotes esophageal cancer growth by activating PI3K-AKT signaling
}

\author{
Yingge Liu ${ }^{1,2+}$, Meiying Zhang ${ }^{2 \dagger}$, Tao He ${ }^{3}$, Weili Yang ${ }^{2}$, Lidong Wang ${ }^{4}$, Lirong Zhang ${ }^{4}$ and Mingzhou Guo ${ }^{2,4^{*}}$ (D)
}

\begin{abstract}
Background: There are seven insulin-like growth factor binding proteins (IGFBPs) that bind insulin-like growth factors (IGFs). IGFBP like protein1 (IGFBPL1) is a new member of this family. The function and mechanism of IGFBPL1 in esophageal cancer remains to be elucidated.

Methods: Eight esophageal cancer cell lines, 114 cases of esophageal dysplasia, and 501 cases of primary esophageal cancer samples were examined in this study. Methylation-specific polymerase chain reaction (MSP), immunohistochemistry, Western blot, flow cytometry, RNA interference assay, and xenograft mouse models were employed.

Results: The expression of IGFBPL1was lost and complete methylation was found in KYSE150 and KYSE410 cells. Reduced expression and partial methylation of IGFBPL1 was found in Bic1, KYSE140, KYSE450, KYSE520, and COLO680N cells. High expression and unmethylation was detected in KYSE510 cells. Restoration of IGFBPL1 expression was found in KYSE150 and KYSE410 cells and the expression of IGFBPL1 was increased in Bic1, KYSE140, KYSE450, KYSE520, and COLO680N cells, after 5AZA-2'-deoxycytidine treatment. IGFBPL1 was methylated in 47.3\% (53/114) of esophageal dysplasia and 49.1\% (246/501) of human primary esophageal squamous cell carcinoma (ESCC). Methylation of IGFBPL1 was significantly associated with TNM stage $(p=0.012)$, and tumor size $(p=0.009)$. IGFBPL1 inhibited esophageal cancer cell clonal formation and proliferation and induced cell apoptosis and G1/S phase arrest. Further study found that IGFBPL1 is involved in PI3K-AKT signaling and IGFBPL1 suppressed human ESCC xenografts growth in mice.
\end{abstract}

Conclusion: IGFBPL1 suppresses esophageal cancer cell growth by inhibiting PI3K-AKT signaling in vitro and in vivo. IGFBPL1 is a novel tumor suppressor in human esophageal cancer.

Keywords: IGFBPL1, DNA methylation, Esophageal cancer, PI3K-AKT

\section{Introduction}

Esophageal cancer is the sixth most common cause of cancer related death worldwide [1]. The prognosis of esophageal cancer remains poor with the overall 5 -year survival ranging from 15 to $25 \%$ [2, 3]. Esophageal cancer mainly consists of two cell types, esophageal squamous cell carcinoma (ESCC), and adenocarcinoma (EAC). ESCC is the predominant histological type and accounts for $90 \%$ of the cases of esophageal carcinoma worldwide [4]. The

\footnotetext{
* Correspondence: mzguo@hotmail.com

${ }^{\dagger}$ Yingge Liu and Meiying Zhang contributed equally to this work.

${ }^{2}$ Department of Gastroenterology \& Hepatology, Chinese PLA General Hospital, \#28 Fuxing Road, Beijing 100853, People's Republic of China ${ }^{4}$ State Key Laboratory of Esophageal Cancer Prevention and Treatment, 40 Daxue Road, Zhengzhou, Henan 450052, People's Republic of China Full list of author information is available at the end of the article
}

so-called "Asian esophageal cancer belt," extending from northern Iran through central China, represents a particularly high-risk area for ESCC, with China alone accounting for more than half of global cases [5].

To identify the genetic differences between ESCC and EAC, Agrawal et al. performed exomic sequencing on 11 cases of EAC and 12 cases of ESCC from the USA. Interestingly, inactivating mutations of $\mathrm{NOTCH} 1$ were identified in $21 \%$ of ESCCs but not in EACs. Notably, NOTCH1 mutations were more frequent in North American ESCCs (11 of 53) compared to ESCCs from China (1 of 48 cases) according to Sanger sequencing validation [6]. Using whole genomic sequencing of ESCC samples from China, Song et al. found that somatic aberrations are mainly involved in the Notch, Wnt, and

(c) The Author(s). 2020 Open Access This article is distributed under the terms of the Creative Commons Attribution 4.0 International License (http://creativecommons.org/licenses/by/4.0/), which permits unrestricted use, distribution, and 
cell cycle pathways [7]. In addition to NOTCH1 mutations, $\mathrm{Hu}$ et al. revealed frequent mutations in PIK3CA and PTEN in ESCC [8].

Epigenetics stands at the interface of the genome, development, and environmental exposure [9]. DNA methylation is the most useful epigenetic marker for human disease studies because it is stable [10]. A great deal of epidemiologic evidence supports a relationship between dietary exposure in early life and long-term health [11]. Moreover, diet can cause profound changes in the epigenome, leading to human disease [9]. Aberrant DNA methylation has been reported in genes involved in cell cycle, DNA damage repair, Wnt, TGF- $\beta$, and NF-kB pathways [12, 13].

The insulin-like growth factor binding proteins (IGFBPs) bind to insulin-like growth factors (IGFs) and regulate their functions. Based on differential affinities to insulin growth factors (IGFs), IGFBPs are classified into two groups: IGF high-affinity binding proteins (IGFBP1-6) and IGF low-affinity binding proteins, such as IGFBP-related proteins (IGFBPRp1-10). IGFBP like protein1 (IGFBPL1) is another member of IGFBPs family [14, 15]. IGFBPL1 was reported to be involved in neural development through PI3K signaling [16]. The expression of IGFBPL1 was reduced in breast cancer, and its expression was regulated by promoter region methylation [17]. The expression and function of IGFBPL1 in esophageal cancer remain to be elucidated.

\section{Materials and methods}

\section{Human tissue samples and cell lines}

A total of 501 cases of ESCC, 114 cases of esophageal dysplasia, and 5 cases of normal esophageal mucosal were collected from the Chinese PLA General Hospital in Beijing. The collection of all samples was based on the approval and guidelines of the Institutional Review Board of the Chinese PLA General Hospital. Among ESCC patients, 316 cases were male and 185 cases were female. The median age was 63 years old (range 41-87 years old). All cancer samples were classified according to the TNM staging system (AJCC2018), including tumor stage I $(n=30)$, stage II $(n=112)$, stage III $(n=333)$, and stage IV $(n=16)$. Eight esophageal cancer cell lines were employed in this study, including Bic1, KYSE140, KYSE410, KYSE450, KYSE150, KYSE520, KYSE510, and COLO680N cells. All cell lines were previously established from primary esophageal cancer and maintained in 90\% RPMI media 1640 (Invitrogen, CA, USA) supplemented with $10 \%$ fetal bovine serum. Cells were passaged 1:3 when total confluence $\left(\sim 10^{6}\right.$ cells $)$ was reached in a $75 \mathrm{~cm}^{2}$ culture flask (NEST Biotechnology, Jiangsu, China).

\section{5-AZA-2'-deoxycytidine treatment}

The esophageal cancer cell lines were seeded in $10 \mathrm{~cm}^{2}$ culture dishes (30\% confluency) $12 \mathrm{~h}$ before treatment with $2 \mathrm{M}$ of 5-AZA-2'-deoxycytidine (5-AZA, Sigma, MO, USA). RPM1640 medium containing 5-AZA-2'deoxycytidine was changed every $24 \mathrm{~h}$ for a total of $96 \mathrm{~h}$.

\section{RNA isolation and semi-quantitative RT-PCR}

Total RNA was extracted using Trizol Reagent (Life Technologies, Carlsbad, CA, USA), quantified by spectrophotometer and qualified by agarose gel electrophoresis.

First-strand cDNA was synthesized according to the manufacturer's instructions (Invitrogen, Carlsbad, CA, USA). A total of $5 \mu \mathrm{g}$ RNA was used to synthesize the first-strand cDNA and diluted to $100 \mu \mathrm{l}$. Subsequently, $2 \mu \mathrm{l}$ of diluted cDNA mixture was used for PCR amplification in a final $25-\mu \mathrm{l}$ reaction volume. PCR primer sequences for IGFBPL1 were as follows: 5'-GTGAGGGCTGTGCC TACCC-3' (F), 5'-CATCA CATGCGGTCATCGGG-3' (R). PCR amplification was for 35 cycles, and the length of products is $308 \mathrm{bp}$. The primers for GAPDH were as follows: 5'-GACCACAGTCCATGCCATCAC-3' (F), and 5'GTCCACCACCCTGTTGCTG TA-3' (R). As an internal control, GAPDH was amplified for 25 cycles. The amplified PCR products were examined by $2 \%$ agarose gels.

\section{DNA extraction, bisulfite modification, methylation- specific PCR, and bisulfite sequencing}

DNA was prepared by the proteinase $\mathrm{K}$ method. Bisulfite treatment was performed as previously described [18, 19]. Methylation-specific PCR (MSP) primers were designed according to genomic sequences around transcriptional start sites (TSS) and synthesized to detect unmethylated (U) and methylated (M) alleles. Bisulfite sequencing (BSSQ) was performed as previously described [20]. BSSQ products were amplified by primers flanking the targeted regions including MSP products. MSP primers were as follows: 5' -TGTAGGTTCGGTTA ATTAGCGGTCGC-3' (MF) and 5'-GAAACAACGA CGACGCCTCTACTTCG-3' (MR); 5'-GGTGTAGGTT 'TGGTT AATTAGTGGTTGT-3' (UF) and 5'CCAAAACAACAACAACACCTCTACTTA-3' (UR). BSSQ primers were as follows: $5^{\prime}$-TYGGGTTGGA GTAGYGGTT-3' (F) and 5'-AAACRCCRAACAAC CCTCTAA-3' (R). MSP amplification conditions were as follows: $95^{\circ} \mathrm{C} 5 \mathrm{~min}, 1 \mathrm{cycle} ; 95^{\circ} \mathrm{C} 30 \mathrm{~s}, 60^{\circ} \mathrm{C} 30 \mathrm{~s}$, and $72{ }^{\circ} \mathrm{C} 40 \mathrm{~s}, 35$ cycles; and $72^{\circ} \mathrm{C} 5 \mathrm{~min}, 1$ cycle. BSSQ PCR amplification conditions were as follows: $95^{\circ} \mathrm{C} 5 \mathrm{~min}, 1$ cycle; $95^{\circ} \mathrm{C} 30 \mathrm{~s}, 64{ }^{\circ} \mathrm{C} 30 \mathrm{~s}$, and $72{ }^{\circ} \mathrm{C} 45 \mathrm{~s}, 3$ cycles; $95^{\circ} \mathrm{C} 30 \mathrm{~s}, 61^{\circ} \mathrm{C} 30 \mathrm{~s}$, and $72{ }^{\circ} \mathrm{C} 45 \mathrm{~s}, 3$ cycles; $95^{\circ} \mathrm{C} 30 \mathrm{~s}$, $58^{\circ} \mathrm{C} 30 \mathrm{~s}$, and $72{ }^{\circ} \mathrm{C} 45 \mathrm{~s}, 3$ cycles; $95^{\circ} \mathrm{C} 30 \mathrm{~s}, 55^{\circ} \mathrm{C} 30 \mathrm{~s}$, and $72{ }^{\circ} \mathrm{C} 45 \mathrm{~s}, 26$ cycles; and $72{ }^{\circ} \mathrm{C} 5 \mathrm{~min}, 1$ cycle. 


\section{Construction of lentiviral IGFBPL1 expression vector and screening of stably expressing cell lines}

Human full-length IGFBPL1 coding DNA sequence (GenBank accession number: NM_001007563) was cloned into the pCDH-CMV-MCS-puro vector. The primers used were 5'-GCCACCATGCCGCGCTTGTCTCTGCTC-3' (F) and 5'-CGCTCGAGTCACATGCGGTCATCGGGAG-3'(R). The HEK-293 T cell line was maintained in DMEM (Invitrogen, CA, USA) supplemented with $10 \%$ fetal bovine serum. IGFBPL1 expressing lentiviral vector was transfected into HEK-293 T cells $\left(5 \times 10^{6}\right.$ per $100-\mathrm{mm}$ dish $)$ using Lipofectamine 3000 Reagent (Invitrogen, CA, USA) at a ratio of 1:3 (DNA mass: Lipo mass). Lentivirus was added to the growing medium of KYSE150 and KYSE410 cells, and IGFBPL1 stably expressed cells were selected by puromycin at a concentration of $2 \mu \mathrm{g} / \mathrm{ml}$ (KYSE150) or $1.5 \mu \mathrm{g} / \mathrm{ml}$ (KYSE410) for 3 days.

\section{RNA interference assay}

Selected siRNAs targeting IGFBPL1 and the RNAi negative control duplex were used in this study. RNAi negative control duplex: 5'-UUCUCCGAACGUGUCACGUTT-3' (F); 5'-ACGUGACACGUCGGAGAATT-3' (R); silGFBPL1847: 5'-GCUCCCGAUGACCGCAUGUTT-3' (F); 5'ACAU GCGGUCAUCGGGAGCTT-3' (R); silGFBPL1-482: 5'-GCGAGUUCGCUCCUG UGGUTT-3' (F); 5'-ACCACAGGAGCGAACUCGCTT-3' (R). The RNAi oligonucleotide and RNAi negative control duplex were transfected into KYSE510 cells, which expressed high levels of IGFBPL1.

\section{Colony formation assay}

IGFBPL1 unexpressed and stably expressed cells (KYSE150 and KYSE410) were seeded at 400 cells per well in 6-well culture plates in triplicate. Before and after the knockdown of IGFBPL1, KYSE510 cells were seeded in 6well plates at a density of 400 cells per well. After 12 days, cells were fixed with $75 \%$ ethanol for $30 \mathrm{~min}$ and stained with $0.2 \%$ crystal violet. The number of clones was then counted. Each experiment was repeated three times.

\section{Cell viability assay}

Cells were plated into 96-well plates at a density of $2.5 \times$ $10^{3}$ cells per well, and cell viability was measured by the methyl thiazolyl tetrazolium (MTT) assay (KeyGEN Biotech, Nanjing, China) at 0, 24, 48, and $72 \mathrm{~h}$. Absorbance was measured on a microplate reader (Thermo Multiskan MK3 [Thermo Fisher Scientific, Danvers, MA, USA]) at a wavelength of $490 \mathrm{~nm}$.

\section{Flow cytometry}

IGFBPL1 unexpressed and re-expressed KYSE150 and KYSE410 cells were starved for $12 \mathrm{~h}$ and then stimulated with $10 \%$ FBS for $24 \mathrm{~h}$. Cells were fixed with $70 \%$ ethanol and treated using the Cell Cycle Detection Kit
(KeyGEN Biotech). The cells were then analyzed by a FACS Caliber flow cytometer (BD Biosciences, Franklin Lakes, NJ, USA). The same method was used to analyze KYSE510 cells before and after IGFBPL1 knockdown. Cell phase distribution was analyzed using MODFIT software (Verity Software House, ME, USA). KYSE150 and KYSE410 cells were transiently transfected with pcDNA3.1+ and pcDNA3.1+ IGFBPL1 vectors. Cell apoptosis was analyzed by FITC Annexin V assay kit according to the manufacturer's instructions (BD Bioscience, Franklin). Apoptosis of KYSE510 cells with or without knockdown of IGFBPL1 was also analyzed. Each experiment was repeated three times.

\section{Western blot}

Proteins from esophageal cancer cells were collected and Western blot was performed as described previously [21]. Antibodies were diluted according to the manufacturer's instructions. Antibodies were as follows: IGFBPL1 (RD,MN,US); Cleaved caspase-3 (Cell Signaling Technology, Danfoss, MA, USA); BCL2 (Cat: 12789-1-AP, Proteintech, USA); CyclinE1 (Cat: 11554-1-AP, Proteintech, USA); CyclinA2 (Cat: 18202-1-AP, Proteintech, USA); CyclinD1 (Cat: 60186-lg, Proteintech,USA); AKT (Cat: 60203-2-lg, Proteintech, USA); p-AKT (Cat: 664441-lg, Proteintech, USA); mTOR (Cat: 2983S, Cell signaling technology); p-mTOR (HuaXingBoChuang, China); PI3K (Cat: 20584-1-AP, Proteintech, USA); MYC (Cat: 10828-1-Ap, Proteintech, USA), and $\beta$-actin (Cat: AF0003, Beyotime Biotech, Jiangsu, China).

\section{Immunohistochemistry}

Immunohistochemistry (IHC) analysis was performed in human ESCC samples and paired adjacent tissue samples. The IGFBPL1 antibody was diluted to 1:400 (CAT: bs15569R, BIOSS), PI3K antibody was diluted to 1:400 (Cat: 20584-1AP, Proteintech, USA), p-mTOR antibody was diluted to 1 : 200 (HuaXingBoChuang, China), and p-AKT antibody was diluted to 1:200 (Cat: 66444-1-lg, Proteintech, USA). The staining intensity and range of the stained areas were scored using the German semi-quantitative scoring system as previously described [20, 22, 23]. The staining intensity of IGFBPL1 expression was quantified as follows: no staining = 0 , weak staining $=1$, moderate staining $=2$, and strong staining $=3$; the extent of staining was defined as follows: $0 \%=0$, $1-24 \%=1,25-49 \%=2,50-74 \%=3$, and $75-100 \%=4$. The final immune response score (0-12) was determined by multiplying the intensity score by the staining score.

\section{Xenograft mouse model}

The unexpressed and stably expressed KYSE150 cells $\left(4 \times 10^{6}\right.$ cells in $0.15 \mathrm{ml}$ phosphate buffer) were injected subcutaneously into the right dorsal side of female Balb/ c nude mice of 4 weeks old $(n=5)$. Tumor volume was 
measured every 4 days for 24 days starting 4 days after implantation. The tumor volume was calculated according to the $V=L \times W^{2} / 2$ formula, where $V$ represents the volume $\left(\mathrm{mm}^{3}\right), L$ represents the largest diameter $(\mathrm{mm})$, and $W$ represents the minimum diameter $(\mathrm{mm})$. All procedures were approved by the Animal Ethics Committee of the Chinese PLA General Hospital.

\section{Data analysis}

RNA-Seq data for expression of IGFBPL1 in the esophageal cancer tissue dataset were downloaded from the Tumor Genome Atlas (TCGA) (http://xena.ucsc.edu/, 04/6/2019). IGFBP1-6 RNA expression data were extracted from the Tumor Genome Atlas (TCGA) dataset for esophageal cancer tissue samples and IGFBP1-6 RNA expression data for normal esophagus were extracted from GTEx (http://xena.ucsc.edu/, 21/12/2019). Statistical analysis was performed using SPSS 17.0 software (SPSS, Chicago, IL, USA). All data are presented as means plus or minus SD and analyzed using the Student's $t$ test. The chi-square test and the Fisher's exact test were used to analyze the association between IGFBPL1 methylation status and clinicopathologic factors, as well as the association between IGFBPL1 expression and methylation status. A $p<0.05$ was considered to be statistically significant.

\section{Results}

The expression of IGFBPL1 is downregulated by promoter region methylation in esophageal cancer cell lines

IGFBPL1 expression was detected by semi-quantitative RT-PCR in esophageal cancer cell lines. Reduced expression of IGFBPL1 was observed in Bic1, KYSE140, KYSE450, KYSE520, and COLO680N cells. High-level expression of IGFBPL1 was detected in KYSE510 cells, while the expression of IGFBPL1 was absent in KYSE410 and KYSE150 cells (Fig. 1a).

Promoter region methylation status was detected by MSP. Unmethylation was found in KYSE510 cells, partial methylation was observed in Bic1, KYSE140, KYSE450, KYSE520, and COLO680N cells, and complete methylation was found in KYSE410 and KYSE150 cells (Fig. 1b). The expression of IGFBPL1 was inversely associated with promoter region methylation. To further reveal that the expression of IGFBPL1 is regulated by promoter methylation, cells were treated with 5-AZA. As expected, the levels of IGFBPL1 expression were unchanged in KYSE510 cells after 5-AZA treatment, while the expression of IGFBPL1 increased in Bic, KYSE140, KYSE450, KYSE520 and COLO680N cells, and the expression of IGFBPL1 was restored in KYSE410 and KYSE150 cells (Fig. 1a). To further validate the efficiency of MSP primers and explore the methylation density of esophageal squamous cancer cells, BSSQ technique was employed. As shown in Fig. 1c, IGFBPL1 was completely methylated in KYSE150 and KYSE410 cells, partially methylated in KYSE450 cells, and unmethylated in KYSE510 cells. These results were consistent with the MSP results. Taken together, these results suggested that the expression of IGFBPL1 is regulated by promoter region methylation in esophageal cancer cells.

\section{IGFBPL1 is frequently methylated in human esophageal dysplasia and ESSC}

The Cancer Genome Atlas (TCGA) database was employed to predict whether the expression of IGFBPL1 is regulated by promoter region methylation. RNA expression and methylation data were extracted from the TCGA database (http://xena.ucsc.edu/) for 186 cases of esophageal primary cancer. IGFBPL1 methylation was only analyzed in 10 CpG sites. Reduced expression of IGFBPL1 was associated with cg-16,918,846 site methylation, which is located in the promoter region (Fig. 2a, b, $p<0.001$ ). These results further indicated that the expression of IGFBPL1 is regulated by promoter region methylation.

IGFBPL1 methylation was detected by MSP in 114 cases of dysplasia, 501 cases of primary ESCC, and 5 cases of normal esophageal mucosa. IGFBPL1 was methylated in $47.3 \%$ (53/114) of esophageal dysplasia and $49.1 \%(246 / 501)$ of human primary ESCC, while no methylation was found in normal esophageal mucosa (Fig. 2c). Methylation of IGFBPL1 was significantly associated with TNM stage $(p=0.012)$ and tumor size $(p=0.009)$ (Table 1$)$, whereas it was not associated with age, gender, lymph node metastasis, tumor cell differentiation, cancer embolus, distal metastasis, smoking, alcohol consumption, or family history (all $p>0.05$ ). To further analyze whether IGFBPL1 expression is regulated by promoter region methylation, 70 cases of available matched esophageal cancer and adjacent tissue samples were evaluated by IHC analysis. IGFBPL1 staining was found in both the nucleus and cytoplasm of the esophagus. IGFBPL1 was highly expressed in the paired paracancerous tissues, while expression was reduced in cancer tissues (Fig. 2d, e, $p<0.001$ ). The reduced expression of IGFBPL1 was significantly associated with promoter region hypermethylation (Fig. 2f, $p<$ $0.001)$. These results further suggested that the expression of IGFBPL1 is regulated by promoter region methylation in human esophageal cancer.

\section{IGFBPL1 inhibits esophageal cancer cell proliferation}

To evaluate the effect of IGFBPL1 expression on cell growth, the MTT assay was employed. The OD values were $0.9607 \pm 0.0603$ vs. $0.6034 \pm 0.0299$ in KYSE150 cells $(t$ test, $p<0.01)$ and $0.8575 \pm 0.0820$ vs. $0.6167 \pm 0.0108$ ( $t$ test, $p<0.01)$ in KYSE410 cells before and after the restoration of IGFBPL1 expression (Fig. 3a). The OD values were $1.3924 \pm 0.0304$ 


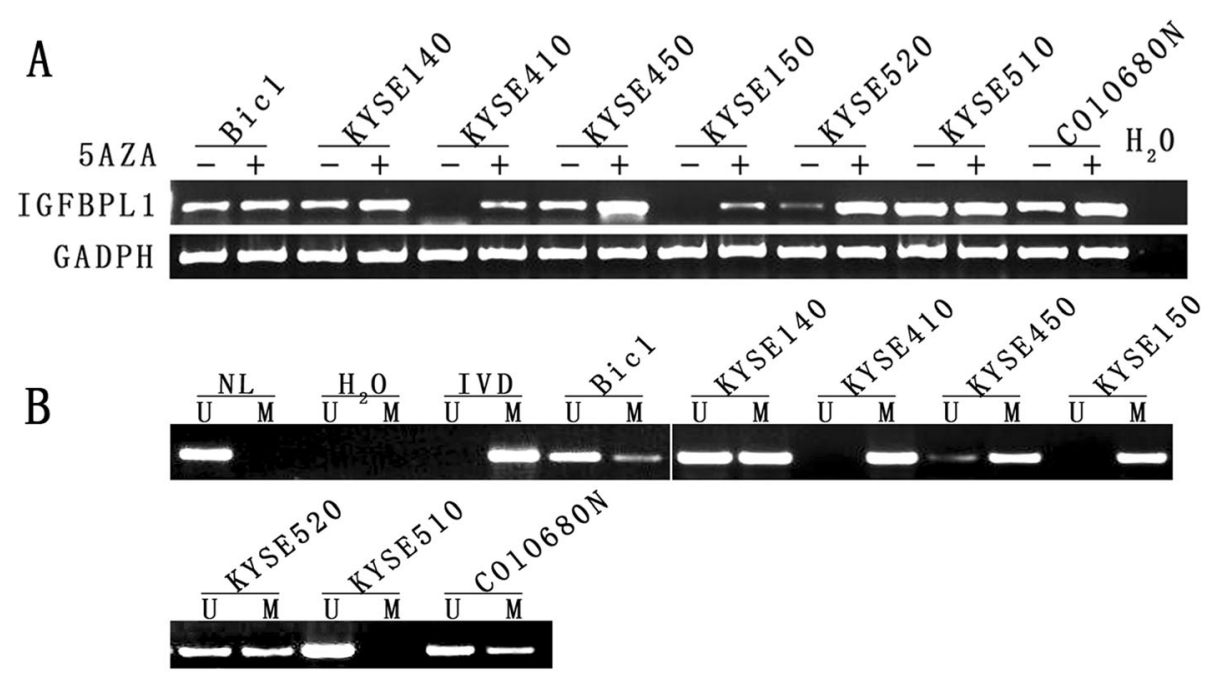

C

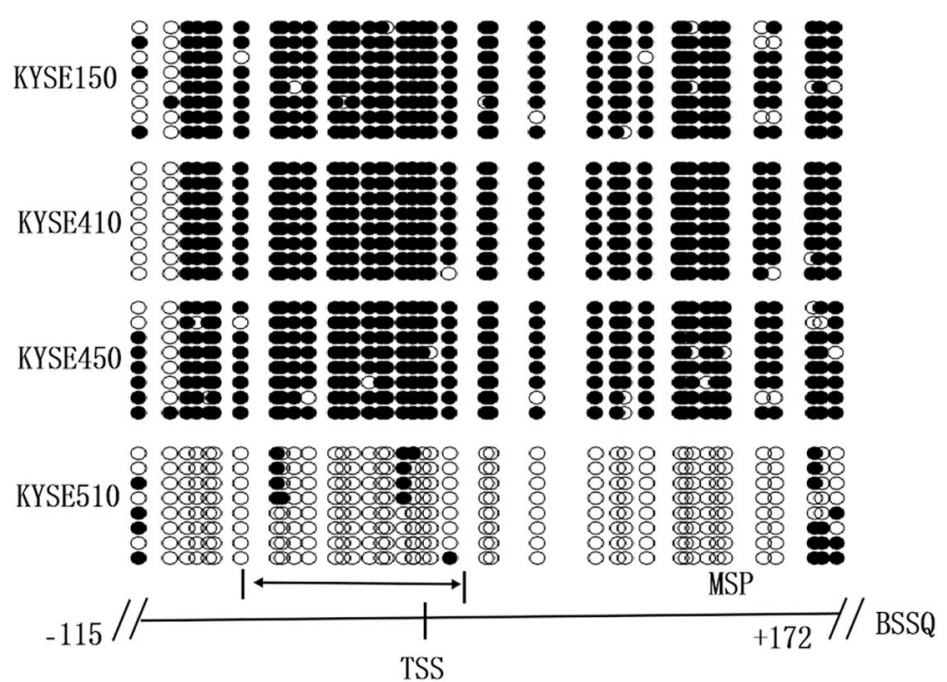

Fig. 1 IGFBPL1 expression and methylation status in esophageal cancer cells. a The expression of IGFBPL1 was detected by semi-quantitative RT-PCR. $\mathrm{H}_{2} \mathrm{O}$, negative control; GAPDH, internal control. 5-AZA, 5-AZA-2'-deoxycytidine. "-" indicates the absence of 5-AZA; "+" indicated the presence of 5-AZA. b MSP results of IGFBPL1 in esophageal cancer cell lines. IVD, in vitro-methylated DNA (methylation control); NL, normal lymphocyte DNA (unmethylation control); $\mathrm{H}_{2} \mathrm{O}$, double distilled water; $\mathrm{U}$, unmethylated alleles; M, methylated alleles. c Bisulfite sequencing results of IGFBPL1 in KYSE150, KYSE410, KYSE450, and KYSE510 cells. Doubleheaded arrow indicates MSP PCR product size was 98 bp and bisulfite sequencing focused on a 287 bp region of the CpG island (from - 115 to +172 ) around the IGFBPL1 transcription start site. Filled circles indicate methylated CpG sites. Open circles indicate unmethylated CpG sites; TSS: transcription start site

vs. $1.6345 \pm 0.0652$ ( $t$ test, $p<0.001)$ in KYSE510 before and after the knockdown of IGFBPL1 (Fig. 3a). These results demonstrated that IGFBPL1 inhibits esophageal cancer cell viability.

The effect of IGFBPL1 on cell proliferation was detected by colony formation assays. The clone numbers were $52 \pm 1.4$ vs.11 \pm 1.1 in KYSE150 cells ( $t$ test, $p<$ $0.01)$ and $47 \pm 1.2$ vs. $15 \pm 1.1$ in KYSE410 cells $(t$ test, $p<0.01)$ before and after over-expression of IGFBPL1 (Fig. 3b). The clone numbers were $8 \pm 1.3$ vs.18 \pm 3.0 ( $t$ test, $p<0.001$ ) in KYSE510 cells before and after the knockdown of IGFBPL1 (Fig. 3b). These results suggested that IGFBPL1 inhibits esophageal cancer cell proliferation.
IGFBPL1 induces esophageal cancer cell apoptosis

Flow cytometry was used to analyze the effect of IGFBPL1 on apoptosis. The ratios of apoptotic cells in IGFBPL1 unexpressed and re-expressed cells were $13.18 \pm 0.18 \%$ vs. $23.88 \pm 0.15 \%$ ( $t$ test, $p<0.001$ ) in KYSE150 cells and $10.32 \pm 0.17 \%$ vs. $19.28 \pm 0.14 \%(t$ test, $p<0.01$ ) in KYSE410 cells (Fig. 3c). The proportion of apoptotic cells increased significantly after re-expression of IGFBPL1 in KYSE150 and KYSE410 cells. The percentage of apoptotic cells before and after knockdown of IGFBPL1 in KYSE510 cells was $30.06 \pm 0.12 \%$ vs. $18.87 \pm 0.14 \%$ ( $t$ test, $p<0.01$, Fig. $3 \mathrm{c})$. The percentage of apoptotic cells was significantly reduced after knockdown of IGFBPL1. To 
A
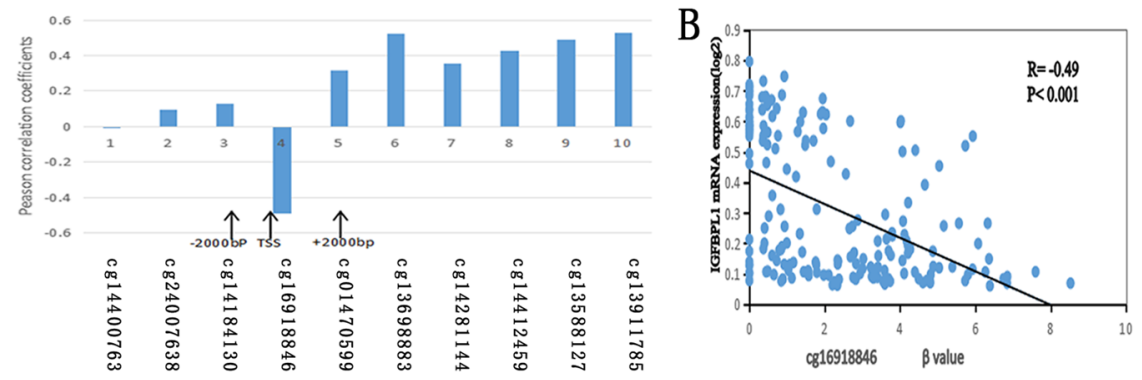

C
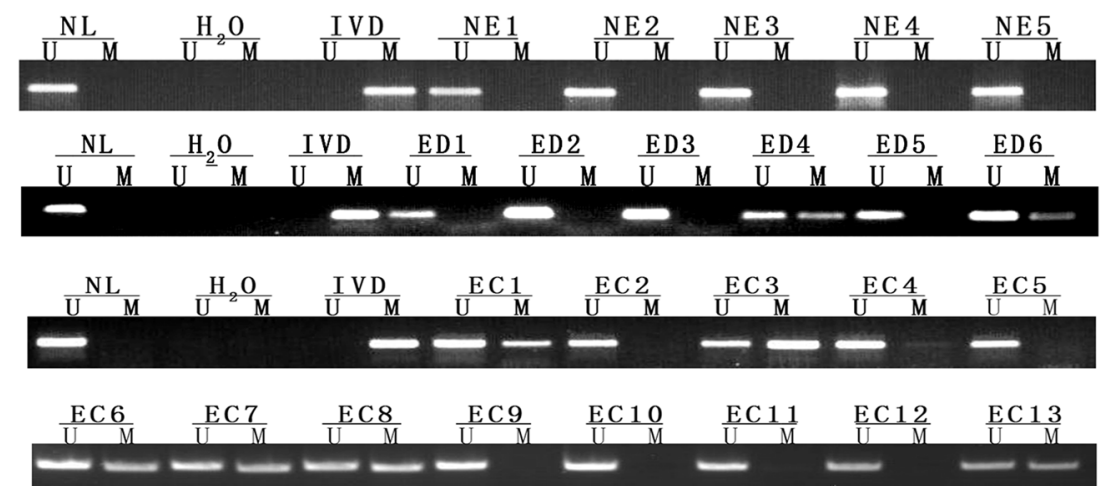

D

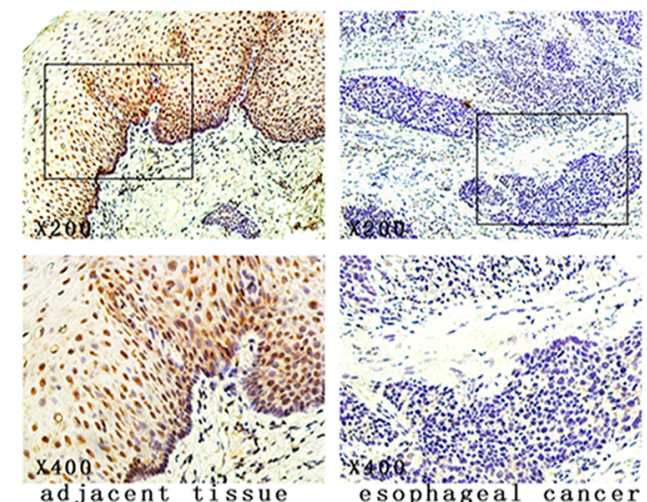

E

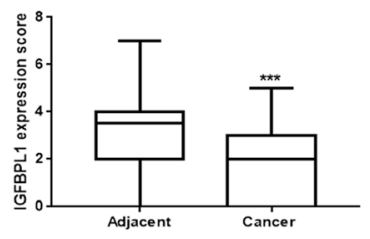

$\mathrm{F}$

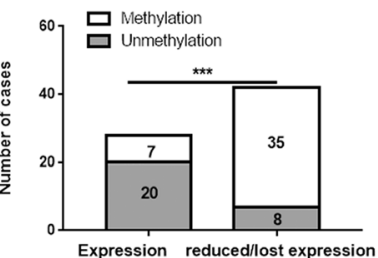

Fig. 2 The expression and methylation status of IGFBPL1 in human esophageal dysplasia and ESCC. a Pearson correlation coefficient between IGFBPL1 methylation and expression of each CpG site. b Scatter plots showing the methylation status of the 4th (cg16918846) CpG sites, which are correlated with loss or reduced IGFBPL1 expression in 186 cases of ESCC tissue samples. ${ }^{* * *} p<0.001$. c Representative methylation results of IGFBPL1 in normal esophageal mucosa (NE), esophageal dysplasia (ED), and esophageal cancer (EC). The frequency of IGFBPL1 methylation was analyzed by chi-square test. $\mathbf{d}$ Representative IHC staining of IGFBPL1 in esophageal cancer (right panels) and adjacent tissue (left panels). Upper panels, $\times 200$; lower panels, $\times 400$. e The IGFBPL expression score is shown as a block diagram; the horizontal line represents the median score; the bottom and top of the box represent the 25th and 75th percentile, respectively; and the vertical bar chart indicates the scope of the data. There were significant differences in the expression of IGFBPL1 in adjacent tissues and cancer tissues in 70 cases of esophageal cancer. ${ }^{* *} p<$ 0.001. f The expression of IGFBPL1 and DNA methylation status is shown as a bar diagram. Reduced or lost expression of IGFBPL1 was significantly associated with promoter region hypermethylation. ${ }^{* * *} p<0.001$

further verify the effect of IGFBPL1 on apoptosis of esophageal cancer cells, the expression levels of caspase-3, cleaved-caspase-3, and Bcl-2 in esophageal cancer cells were analyzed. As shown in Fig. 3f, the levels of caspase-3 decreased and the levels of cleaved-caspase-3 and Bcl-2 decreased after IGFBPL1 was re-expressed in KYSE150 and KYSE410 cells. Meanwhile, the levels of caspase- 3 and $\mathrm{Bcl}-2$ increased and the levels of cleaved-caspase- 3 decreased after knockdown of the IGFBPL1 in KYSE510 cells (Fig. 3e, f). These results further suggested that IGFBPL1 induces apoptosis in esophageal cancer cells.

\section{IGFBPL1 induces G1/S phase arrest in esophageal cancer cells}

The effect of IGFBPL1 on cell cycle was analyzed by flow cytometry. In KYSE150 cells, the cell phase distribution 
Table 1 The association of IGFBPL1 methylation and clinical factors in human ESCC

\begin{tabular}{|c|c|c|c|c|}
\hline \multirow[t]{2}{*}{ Clinical factor } & \multirow[t]{2}{*}{ Number } & \multicolumn{2}{|l|}{ IGFBPL1 methylation status } & \multirow{2}{*}{$\begin{array}{l}P \\
\text { value }\end{array}$} \\
\hline & & Unmethylated $n=25550.28 \%$ & Methylated $n=24649.10 \%$ & \\
\hline Age (years) & & & & 0.167 \\
\hline$<63$ & 252 & 136 & 116 & \\
\hline$\geq 63$ & 249 & 119 & 130 & \\
\hline Gender & & & & 0.102 \\
\hline Male & 316 & 152 & 164 & \\
\hline Female & 185 & 103 & 82 & \\
\hline Tumor size $(\mathrm{cm})$ & & & & $0.009^{* *}$ \\
\hline$<4$ & 254 & 144 & 110 & \\
\hline$\geq 4$ & 247 & 111 & 136 & \\
\hline Differentiation & & & & 0.518 \\
\hline Well or moderate & 390 & 200 & 190 & \\
\hline Poor & 111 & 55 & 56 & \\
\hline Lymph node metastasis & & & & 0.131 \\
\hline Negative & 310 & 166 & 144 & \\
\hline Positive & 191 & 89 & 102 & \\
\hline TNM stage & & & & $0.012^{*}$ \\
\hline Stage I-II & 295 & 164 & 131 & \\
\hline Stage III-VI & 206 & 91 & 115 & \\
\hline Distal metastasis & & & & 0.070 \\
\hline Yes & 58 & 36 & 22 & \\
\hline No & 443 & 219 & 224 & \\
\hline Cancer embolus & & & & 0.848 \\
\hline Yes & 15 & 8 & 7 & \\
\hline No & 486 & 247 & 239 & \\
\hline Smoking & & & & 0.277 \\
\hline Yes & 271 & 144 & 127 & \\
\hline No & 230 & 111 & 119 & \\
\hline Drinking & & & & 0.136 \\
\hline Yes & 116 & 52 & 64 & \\
\hline No & 385 & 203 & 182 & \\
\hline Inherited & & & & 0.806 \\
\hline Yes & 136 & 68 & 68 & \\
\hline No & 365 & 187 & 178 & \\
\hline
\end{tabular}

$P$ values are obtained from chi-square test, significant difference

${ }^{*} p<0.05$

${ }^{* *} p<0.01$

patterns before and after re-expression of IGFBPL1 were as follows: $24.74 \pm 0.42 \%$ vs. $28.94 \pm 0.6 \%$ in $\mathrm{G} 0 / \mathrm{G} 1$ phase $(p<0.001), \quad 59.25 \pm 3.35 \%$ vs. $54.83 \pm 0.33 \%$ in $\mathrm{S}$ phase $(p<0.05)$, and $15.67 \pm 1.38 \%$ vs. $16.22 \pm 0.47 \%$ in $\mathrm{G} 2 / \mathrm{M}$ phase $(p>0.05)$ (Fig. 3d). The percentage of cells in G0/ G1 phase increased significantly, whereas the percentage of cells in $\mathrm{S}$ phase decreased significantly after reexpression of IGFBPL1 (Fig. 3d). The cell cycle distribution patterns before and after re-expression of IGFBPL1 in KYSE410 cells were $34.57 \pm 0.87 \%$ vs. $39.58 \pm 0.59 \%$ in G0/G1 phase $(p<0.01), 45.74 \pm 2.32 \%$ vs. $40.82 \pm 0.27 \%$ in $\mathrm{S}$ phase $(p<0.05)$, and $19.28 \pm 0.85 \%$ vs.19.36 $\pm 1.17 \%$ in $\mathrm{G} 2 / \mathrm{M}$ phase $(p>0.05$, Fig. $3 \mathrm{~d})$. The G0/G1 phase cells increased significantly, whereas the $S$ phase cells decreased significantly after re-expression of IGFBPL1 in KYSE410 cells (Fig. 3d). The effect of IGFBPL1 on cell cycle was further validated by knocking down IGFBPL1 in IGFBPL1 highly expressed KYSE510 cells. The 
A
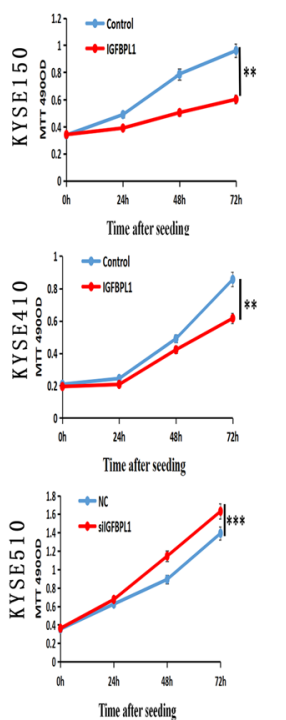

D

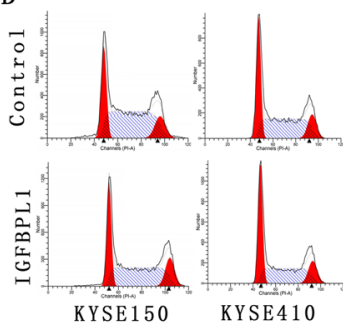

B

C
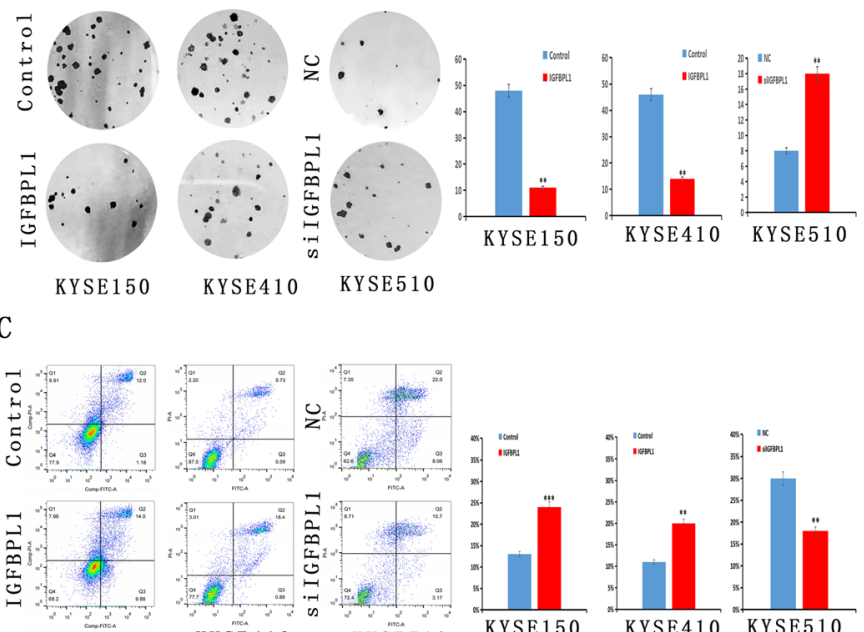

KYSE $150 \quad$ KYSE 410
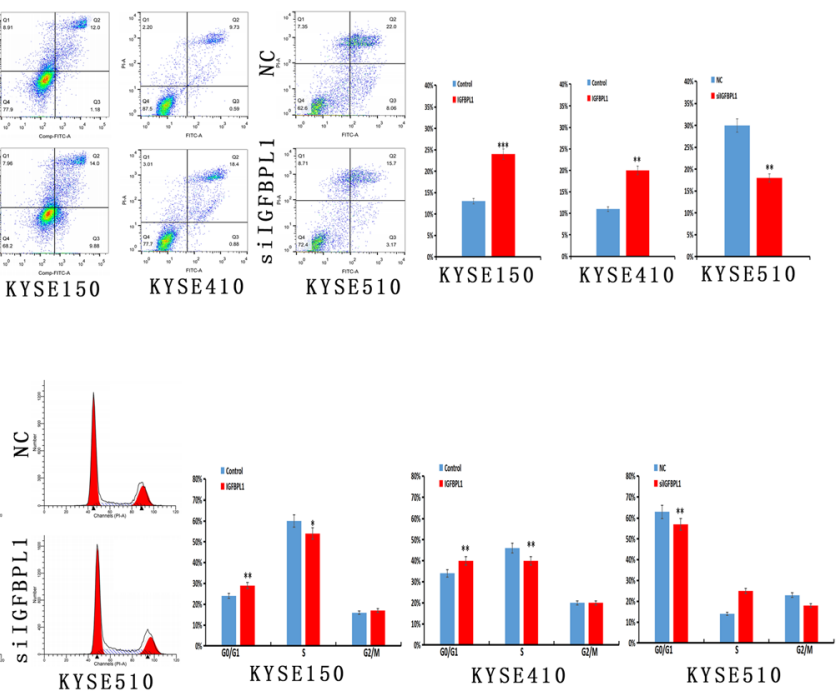

$\mathrm{E}$
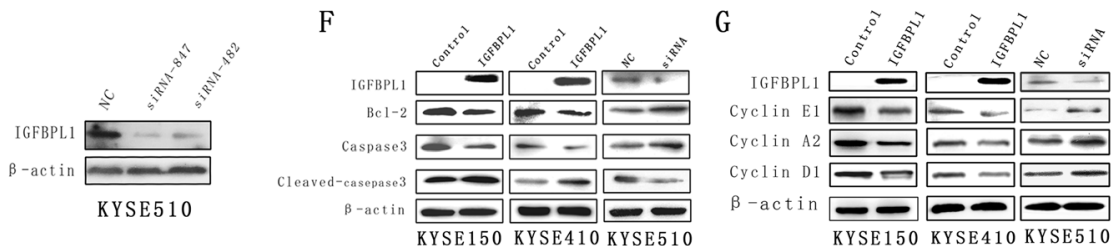

Fig. 3 IGFBPL1 inhibits esophageal cancer cell proliferation and induces cell apoptosis and G1/S phase arrest. a The effect of IGFBPL1 on cell viability was examined by the MTT assay. The growth curves of IGFBPL1 re-expressed and unexpressed KYSE150 and KYSE410 cells, and KYSE510 cells before and after IGFBPL1 gene knockdown, were analyzed. Each experiment was repeated three times. ${ }^{* *} p<0.01$, ${ }^{* * *} p<0.001$. $\mathbf{b}$ Colony formation assays showed that the number of clones decreased after the expression of IGFBPL1 was restored in KYSE150 and KYSE410 cells, while the number of clones of KYSE510 cells increased after IGFBPL1 knockdown. Each experiment was repeated three times. ${ }^{* *} p<0.01,{ }^{* *} p<0.001 . \mathbf{c}^{*}$ Flow cytometry results showed that over-expression of IGFBPL1 in KYSE150 and KYSE410 cells induced apoptosis, whereas apoptosis decreased after knockdown of IGFBPL1 in KYSE510 cells. Each experiment was repeated three times. ${ }^{* *} p<0.01,{ }^{* * *} p<0.001$. d Cell cycle distribution of KYSE150 and KYSE410 cells that had no IGFBPL1 expression or re-expression of IGFBPL1 and KYSE510 before and after knockdown of IGFBPL1. Each experiment was repeated three times. ${ }^{* *} p<0.01,{ }^{* *} p<0.001$. e IGFBPL1 in KYSE510 cells was knocked down by siRNA. IGFBPL1 expression was examined by Western blot. NC, siRNA for IGFBPL1 negative control; siRNA847 and siRNA482, siRNA for IGFBPL1. f Western blots showed that IGFBPL1 has an effect on the expression levels of caspase-3 and BCl-2 in KYSE150, KYSE410, and KYSE510 cells. Control, control vector; IGFBPL1, IGFBPL1 expression vector; $\beta$-actin, internal control; NC, siRNA negative control; siRNA, silGFBPL1. g Western blots validated the effect of IGFBPL1 on the protein expression levels of cyclin E1, cyclin A2, and cyclin D1. Control, control vector; IGFBPL1, IGFBPL1 expressing vector; $\beta$-actin, internal control; NC, siRNA negative control; siRNA, silGFBPL1

distribution of cell phases were $62.29 \pm 0.22 \%$ vs. $57.38 \pm$ $0.68 \%$ in $\mathrm{G} 0 / \mathrm{G} 1$ phase $(p<0.01), 18.89 \pm 1.12 \%$ vs. $26.11 \pm 0.97 \%$ in $\mathrm{S}$ phase $(p>0.05)$, and $18.82 \pm 0.58 \%$ vs. $16.35 \pm 1.02 \%$ in $\mathrm{G} 2 / \mathrm{M}$ phase $(p>0.05$, Fig. $3 \mathrm{~d})$. The distribution of G0/G1 phase increased significantly after knockdown of IGFBPL1 (Fig. 3d). To further validate the effect of IGFBPL1 on cell cycle, the protein expression levels of cyclinE1, cyclinA2, and cyclinD1 were detected in KYSE150 and KYSE410 cells by Western blot before and after re-expression of IGFBPL1. As shown in Fig. 3g, the levels of cyclinE1, cyclinA2, and cyclinD1 decreased after re-expression of IGFBPL1 in KYSE150 and 
KYSE410 cells. The effect of knocking down IGFBPL1 on cyclinE1, cyclinA2, and cyclinD1 expression was verified in KYSE510 cells as well. The levels of cyclinE1, cyclinA2, and cyclinD1 increased after knockdown of IGFBPL1 (Fig. 3g). These results indicated that IGFBPL1 induces G1/S phase arrest in human esophageal cancer cells.

IGFBPL1 inhibits PI3K-AKT signaling in human esophageal cancer cells

IGFBPL1 has been reported to be involved in PI3K-AKT signaling during neural development in mice [15]. To further understand the mechanism of IGFBPL1 in esophageal cancer development, we studied the role of IGFBPL1 in PI3K-AKT signaling in esophageal cancer cells. As shown in Fig. 4a, the levels of PI3K, p-AKT, mTOR, p-mTOR, and MYC were decreased and the levels of AKT were increased after re-expression of IGFBPL1 in KYSE150 and KYSE410 cells, while the levels of PI3K, p-AKT, mTOR, p-mTOR, and MYC were increased and the levels of AKT were reduced after knockdown of IGFBPL1 in KYSE510 cells. These results suggested that IGFBPL1 inhibits PI3K-AKT signaling in esophageal cancer cells.

To further validate the effect of IGFBPL1 on PI3KmTOR signaling, NVP-BEZ235, a PI3K-mTOR inhibitor, was employed, and the MTT assay was used to evaluate cell proliferation ability. The OD values in KYSE510 cells were $0.658 \pm 0.021$ in the control group, $0.611 \pm 0.016$ in control plus NVP-BEZ235 treatment group, $0.993 \pm 0.022$ in silGFBPL1 group, and $0.529 \pm 0.014$ in silGFBPL1 plus NVP-BEZ235 treatment group. No significant differences were found between the control group and control plus NVP-BEZ235 treatment group, as well as between the control group and silGFBPL1 plus NVP-BEZ235 treatment group (both $p>0.05$ ) in IGFBPL1 highly expressed KYSE510 cells. However, the OD value increased significantly in the siIGFBPL1 group compared to the control group ( $p<0.01$ Fig. $4 \mathrm{~b})$, and the OD value decreased significantly in silGFBPL1 plus NVP-BEZ235 group compared to silGFBPL1 group ( $p<0.01$, Fig. $4 \mathrm{~b})$. These results further suggested that IGFBPL1 inhibits PI3K signaling in esophageal cancer cells.

To further verify the effect of IGFBPL1 on PI3K-AKT signaling, the levels of PI3K, AKT, p-AKT, mTOR, pmTOR, and MYC expression were detected by Western blot in IGFBPL1 highly expressed KYSE510 cells with or without NVP-BEZ235 treatment, as well as in siIGFBPL1-treated KYSE510 cells. The levels of PI3K, pAKT, mTOR, p-mTOR, and MYC were decreased after NVP-BEZ235 treatment in KYSE510 cells. The levels of PI3K, p-AKT, mTOR, p-mTOR, and MYC were increased after silGFBPL1 knockdown KYSE510 cells (Fig. 4c). The levels of PI3K, p-AKT, mTOR, p-mTOR, and MYC were reduced after NVP-BEZ235 treatment in
siIGFBPL1 KYSE510 cells (Fig. 4c). These results further suggested that IGFBPL1 is involved in PI3K-AKT signaling in human ESCC.

\section{IGFBPL1 suppresses human esophageal cancer cell xenografts growth by inhibiting PI3K-AKT signaling} To further validate the effect of IGFBPL1 in ESCC, an esophageal cancer cell xenograft mouse model was employed (Fig. 4d). KYSE150 cells before and after reexpression of IGFBPL1 were inoculated subcutaneously in nude mice. The mean tumor volume was $189.53 \pm 18.42$ $\mathrm{mm}^{3}$ and $90.54 \pm 17.29 \mathrm{~mm}^{3}$ in IGFBPL1 unexpressed and re-expressed KYSE150 cell xenografts, respectively. The xenograft volume decreased significantly after re-expression of IGFBPL1 in KYSE150 cells ( $t$ test, $p<0.05$, Fig. $4 \mathrm{e}, \mathrm{f}$ ). The tumor weight was $265.58 \pm 46.86 \mathrm{mg}$ vs. $83.08 \pm 18.12$ mg in IGFBPL1 unexpressed and re-expressed KYSE150 cell xenografts. The tumor weight decreased significantly in IGFBPL1 re-expressed KYSE150 cell xenografts ( $t$ test, $p<$ 0.001 , Fig. $4 g$ ). The expression of IGFBPL1 was validated in IGFBPL1 re-expressed KYSE150 cell xenografts by IHC staining (Fig. 4h, lower panels). These results indicated that IGFBPL1 suppresses esophageal cancer cell growth in vivo.

To further validate whether IGFBPL1 inhibits PI3KAKT signaling in vivo, the levels of PI3K, p-AKT, and pmTOR were detected by IHC staining before and after re-expression of IGFBPL1 in KYSE150 cell xenografts. The expression of PI3K, p-AKT, and p-mTOR decreased in IGFBPL1 re-expressed KYSE150 cell xenografts (Fig. 4h). These results suggested that IGFBPL1 inhibits PI3K-AKT signaling in vivo.

\section{Discussion}

Insulin-like growth factor (IGF) signaling plays important roles in regulating growth and development in normal human tissues by promoting cellular proliferation and differentiation and preventing apoptosis [24, 25]. IGF-1 and IGF-2 are members of the insulin superfamily of growth-promoting peptides and are among the most abundant and ubiquitous polypeptide growth factors [26]. Increased levels of IGF-1 and IGF-2 are associated with many cancers, including esophageal cancer [27-30].

The IGFs are distinguished from insulin by their interaction with six high-affinity IGFBPs [31]. In addition to modulating IGF bioactivity, IGFBP family members have biological actions independent of their abilities to bind IGFs, including binding to a variety of extracellular and cell surface molecules [27]. IGFBPs are cysteine-rich proteins that bind to IGFs with high affinity, thereby enhancing or inhibiting the IGF signaling pathway in a cell-type-dependent manner [15]. Increased expression of IGF1R, IGFBP3, IGFBP4, IGFBP7, and IGFBP8 was reported in human esophageal cancer, while the expression of IGFBP2 and IGFBP6 was reduced [32-35]. While 

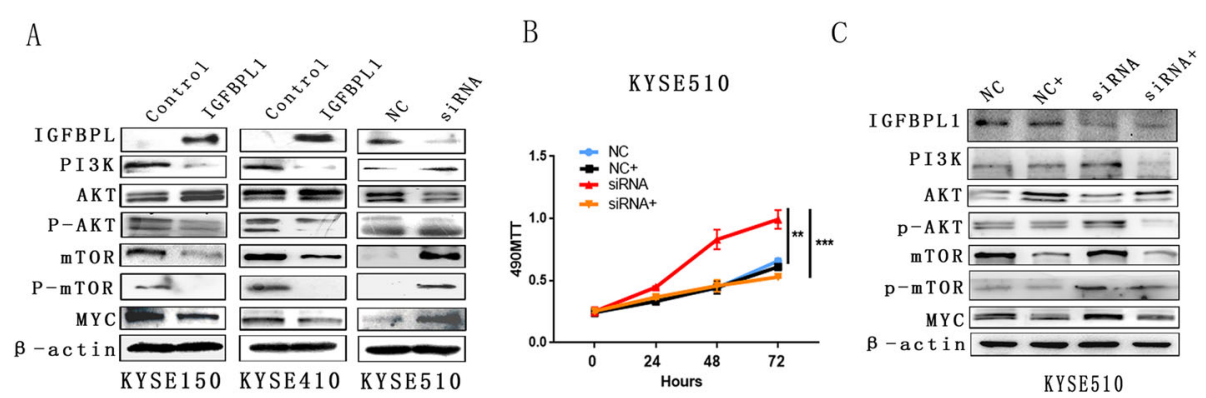

D

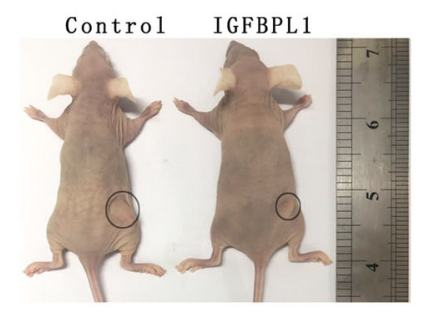

E

E
IG
H
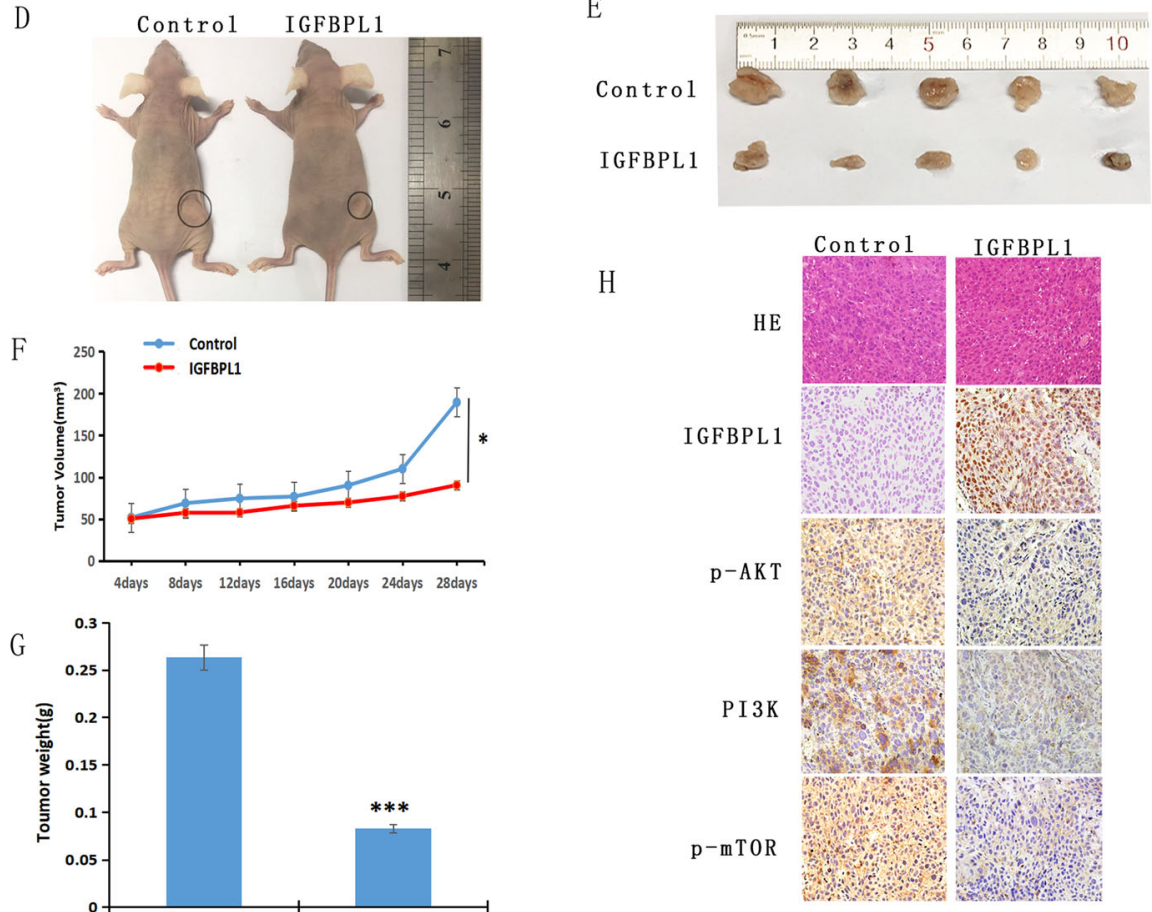

Fig. 4 IGFBPL1 inhibits the PI3K-AKT signaling pathway and suppresses human ESCC cell xenograft growth in mice. a Western blots showed that IGFBPL1 has an effect on the expression levels of PI3K, AKT, p-AKT, mTOR, p-mTOR, and MYC in KYSE150, KYSE410, and KYSE510 cells. Control, control vector; IGFBPL1, IGFBPL1 expression vector; $\beta$-actin, internal control; NC, siRNA negative control; siRNA, silGFBPL1. b Growth curves represent cell viability evaluated by MTT assay in the control group, control plus NVP-BEZ235(100 nM) treatment group, silGFBPL1 group, and silGFBPL1 plus NVP-BEZ235 treatment group in KYSE510 cells. NC, control group; NC+, control plus NVP-BEZ235 treatment group; siRNA, silGFBPL1; siRNA+, silGFBPL1 plus NVP-BEZ235 treatment group. ${ }^{* *} p<0.01$, ${ }^{* * *} p<0.001$. c Western blots showed that IGFBPL1 has an effect on the expression levels of PI3K, AKT, p-AKT, mTOR, p-mTOR, and MYC in KYSE510 cells before and after NVP-BEZ235 treatment. NC, control group; NC+, control plus NVP-BEZ235 treatment group; siRNA, silGFBPL1; siRNA+, silGFBPL1 plus NVP-BEZ235 treatment group. d, e Represents tumors from KYSE150 cell xenografts in which IGFBPL1 is not expressed and IGFBPL1 is over-expressed. $\mathbf{f}$ Tumor growth curves of unexpressed IGFBPL1 and IGFBPL1 overexpressing KYSE150 cells. ${ }^{*} p<0.05$. g Tumor weight at 28th day after inoculation of unexpressed IGFBPL1 and IGFBPL1 overexpressing KYSE150 cells in nude mice. Bars indicate mean of five mice. ${ }^{* *} p<0.001$. $\mathbf{h}$ Images of hematoxylin and eosin staining show tumors from IGFBPL1 unexpressed and IGFBPL1 re-expressed KYSE150 xenograft mice. IHC staining reveals the expression levels of IGFBPL1, pAKT, PI3K, and p-mTOR in IGFBPL1 unexpressed and IGFBPL1 re-expressed KYSE150 cell xenografts. Magnification, $\times 400$

the levels of IGFBP1-6 mRNA expression in TCGA and GTEx database are different with other reports, the expression of IGFBP1 and IGFBP3 were increased in ESCC compared to normal tissue samples (all $p<0.001$ ). The expression of IGFBP5 and IGFBP6 were reduced in ESCC compared to normal tissue samples (all $p<0.001$ ). No significant expression changes were found in IGFBP2 and IGFBP4 in ESCC and normal tissue samples (all $p>$
0.05). No association was found between IGFBPs expression and overall survival in ESCC patients (all $p>0.05$, data not shown). We further evaluated IGFBP1-6 expression in esophageal cancer cells by RT-PCR. Loss of IGFBP1-5 expression was frequently found in esophageal cancer cells, while IGFBP6 was expressed in all cell lines (data not show). To date, no cancers have been attributed to IGFBP mutation [36]. IGFBPL1 was identified in 
1997 (Fujimoto, GenBank Submission, 1997) and is located on chromosome 4 in mouse and chromosome 9 p13.1 in humans. The IGFBPL1 gene was reported to be frequently methylated in human breast cancer and regulated by promoter region methylation, and methylation of IGFBPL1 was associated with poor prognosis [17].

In this study, we found that the expression of IGFBPL1 is regulated by promoter region methylation in human esophageal cancer. IGFBPL1 is frequently methylated in human esophageal dysplasia and ESCC. Methylation of IGFBPL1 is associated with tumor size and TNM stage and therefore may serve as an esophageal cancer early detection marker. Further study found that IGFBPL1 suppresses esophageal cancer cell growth both in vitro and in vivo. IGFBPL1 was reported to initiate axon growth by phosphorylation of PI3K and mTOR during development [16, 37-39]. Then, we analyzed the effect of IGFBPL1 on PI3K-AKT pathway in esophageal cancer. Our results demonstrate that IGFBPL1 inhibited PI3K-AKT signaling in human esophageal cancer cells. Thus, methylation of IGFBPL1 may activate PI3K-AKT signaling in ESCC. These results suggest IGFBPL1 methylation may serve as a predictive marker for PI3Ktargeted therapy in ESCC.

\section{Conclusion}

IGFBPL1 is frequently methylated in human esophageal dysplasia and ESCC, and its expression is regulated by promoter region methylation. Methylation of IGFBPL1 is associated with tumor size and TNM stage. IGFBPL1 suppresses esophageal cancer cell growth by inhibiting PI3K-AKT signaling in vitro and in vivo. Methylation of IGFBPL1 is a potential esophageal cancer early detection marker and a predictive marker for PI3K-targeted therapy in ESCC.

\footnotetext{
Abbreviations

5-AZA: 5-AZA-2'-deoxycytidine; BSSQ: Bisulfite sequencing; EAC: Esophageal adenocarcinoma; ESCC: Esophageal squamous cell carcinoma; GAPDH: Glyceraldehyde-3-phosphate dehydrogenase;

IHC: Immunohistochemistry; IVD: In vitro-methylated DNA; MSP: Methylationspecific PCR; NL: Normal lymphocyte DNA; TCGA: The Cancer Genome Atlas; TSS: Transcription start site
}

\section{Acknowledgments}

We are grateful to Su Xiaomo for preparing for the experiments.

\section{Authors' contributions}

$Y L$ and $M Z$ conducted research and analyzed the data. The manuscript was written by $Y L, M Z$, and $M G$. MG has made significant contributions to the concept and design of this research. YL oversaw the study. All authors read and approved the final manuscript.

\section{Funding}

This work was supported by grants from the National Key Research and Development Program of China (2018YFA0208902), National Science Foundation of China (NSFC no.U1604281, 81672318), Beijing Science Foundation of China (BJSFC no.7171008), National Key Scientific Instrument Special Program of China (grant no. 2011YQ03013405), and Natural Science Foundation of Tianjin (no. 18JCYBJC27900).

\section{Availability of data and materials}

Based on a reasonable request, the data from the current research analysis can be obtained from the corresponding author.

\section{Ethics approval and consent to participate}

This study was approved by the Institutional Review Board of the Chinese PLA General Hospital.

\section{Consent for publication}

We confirm that all authors agree with the submissions currently (and thereafter).

\section{Competing interests}

The authors declare that they have no competing interests.

\section{Author details}

'Department of Life Sciences and Technology, Xinxiang Medical University, Jinsui East Road, Xinxiang 453003, Henan, People's Republic of China. ${ }^{2}$ Department of Gastroenterology \& Hepatology, Chinese PLA General Hospital, \#28 Fuxing Road, Beijing 100853, People's Republic of China. ${ }^{3}$ Department of Pathology, Characteristic Medical Center of the Chinese People's Armed Police Force, Tianjin 300162, People's Republic of China.

${ }^{4}$ State Key Laboratory of Esophageal Cancer Prevention and Treatment, 40

Daxue Road, Zhengzhou, Henan 450052, People's Republic of China.

Received: 7 October 2019 Accepted: 22 January 2020

Published online: 10 February 2020

\section{References}

1. Fitzmaurice C, Dicker D, Pain A, Hamavid H, Moradi-Lakeh M, Maclntyre MF, Allen C, Hansen G, Woodbrook R, Wolfe C, et al. The global burden of Cancer 2013. JAMA Oncology. 2015;1(4):505-27.

2. Huang FL, Yu SJ. Esophageal cancer: risk factors, genetic association, and treatment. Asian J Surg. 2018:41(3):210-5.

3. Pennathur A, Gibson MK, Jobe BA, Luketich JD. Oesophageal carcinoma. Lancet. 2013;381(9864):400-12.

4. Brock MV, Gou M, Akiyama Y, Muller A, Wu TT, Montgomery E, Deasel M, Germonpre P, Rubinson L, Heitmiller RF, et al. Prognostic importance of promoter hypermethylation of multiple genes in esophageal adenocarcinoma. Clin Cancer Res. 2003;9(8):2912-9.

5. Zhang $H Z$, Jin $G F$, Shen $H B$. Epidemiologic differences in esophageal cancer between Asian and Western populations. Chin J Cancer. 2012;31(6):281-6.

6. Agrawal N, Jiao Y, Bettegowda C, Hutfless SM, Wang Y, David S, Cheng Y, Twaddell WS, Latt NL, Shin EJ, et al. Comparative genomic analysis of esophageal adenocarcinoma and squamous cell carcinoma. Cancer Disc. 2012;2(10):899-905.

7. Song Y, Li L, Ou Y, Gao Z, Li E, Li X, Zhang W, Wang J, Xu L, Zhou Y, et al. Identification of genomic alterations in oesophageal squamous cell cancer. Nature. 2014;509(7498):91-5

8. Hu N, Kadota M, Liu H, Abnet CC, Su H, Wu H, Freedman ND, Yang HH, Wang C, Yan C, et al. Genomic landscape of somatic alterations in esophageal squamous cell carcinoma and gastric Cancer. Cancer Res. 2016; 76(7):1714-23.

9. Feinberg AP. The key role of epigenetics in human disease prevention and mitigation. N Engl J Med. 2018;378(14):1323-34

10. Thirlwell C, Eymard M, Feber A, Teschendorff A, Pearce K, Lechner M, Widschwendter M, Beck S. Genome-wide DNA methylation analysis of archival formalin-fixed paraffin-embedded tissue using the Illumina Infinium HumanMethylation27 BeadChip. Methods. 2010:52(3):248-54.

11. Slomko $\mathrm{H}, \mathrm{Heo} \mathrm{HJ}$, Einstein FH. Minireview: epigenetics of obesity and diabetes in humans. Endocrinology. 2012;153(3):1025-30.

12. Cao B, Yang W, Jin Y, Zhang M, He T, Zhan Q, Herman JG, Zhong G, Guo M. Silencing NKD2 by promoter region hypermethylation promotes esophageal cancer progression by activating Wnt signaling. J Thorac Oncol. 2016;11(11):1912-26.

13. Ma K, Cao B, Guo M. The detective, prognostic, and predictive value of DNA methylation in human esophageal squamous cell carcinoma. Clin Epigenetics. 2016:8:43.

14. Cai Z, Chen HT, Boyle B, Rupp F, Funk WD, Dedera DA. Identification of a novel insulin-like growth factor binding protein gene homologue with tumor suppressor like properties. Biochem Biophys Res Commun. 2005;331(1):261-6. 
15. Kashyap MK. Role of insulin-like growth factor-binding proteins in the pathophysiology and tumorigenesis of gastroesophageal cancers. Tumour Biol. 2015;36(11):8247-57.

16. Guo C, Cho KS, Li Y, Tchedre K, Antolik C, Ma J, Chew J, Utheim TP, Huang $X A, Y u H$, et al. IGFBPL1 regulates axon growth through IGF-1-mediated signaling cascades. Sci Rep. 2018;8(1):2054.

17. Smith P, Nicholson L, Syed N, Payne A, Hiller L, Garrone O, Occelli M, Gasco $M$, Crook T. Epigenetic inactivation implies independent functions for insulin-like growth factor binding protein (IGFBP)-related protein 1 and the related IGFBPL1 in inhibiting breast cancer phenotypes. Clin Cancer Res. 2007;13(14):4061-8.

18. Cao B, Yang Y, Pan Y, Jia Y, Brock MV, Herman JG, Guo M. Epigenetic silencing of CXCL14 induced colorectal cancer migration and invasion. Discov Med. 2013;16(88):137-47.

19. Herman JG, Graff JR, Myohanen S, Nelkin BD, Baylin SB. Methylation-specific PCR: a novel PCR assay for methylation status of CpG islands. Proc Natl Acad Sci U S A. 1996:93(18):9821-6.

20. Jia Y, Yang Y, Zhan Q, Brock MV, Zheng X, Yu Y, Herman JG, Guo M. Inhibition of SOX17 by microRNA 141 and methylation activates the WNT signaling pathway in esophageal cancer. J Mol Diagn. 2012;14(6):577-85.

21. Yu Y, Yan W, Liu X, Jia Y, Cao B, Yu Y, Lv Y, Brock MV, Herman JG, Licchesi J, et al. DACT2 is frequently methylated in human gastric cancer and methylation of DACT2 activated Wnt signaling. Am J Cancer Res. 2014;4(6):710-24.

22. Cui Y, Gao D, Linghu E, Zhan Q, Chen R, Brock MV, Herman JG, Guo M Epigenetic changes and functional study of HOXA11 in human gastric cancer. Epigenomics. 2015;7(2):201-13.

23. Yan W, Wu K, Herman JG, Brock MV, Fuks F, Yang L, Zhu H, Li Y, Yang Y, Guo M. Epigenetic regulation of DACH1, a novel Wnt signaling component in colorectal cancer. Epigenetics. 2013;8(12):1373-83.

24. Brahmkhatri VP, Prasanna C, Atreya HS. Insulin-like growth factor system in cancer: novel targeted therapies. Biomed Res Int. 2015;2015:538019.

25. Denduluri SK, Idowu O, Wang Z, Liao Z, Yan Z, Mohammed MK, Ye J, Wei Q, Wang J, Zhao L, et al. Insulin-like growth factor (IGF) signaling in tumorigenesis and the development of cancer drug resistance. Genes Dis. 2015;2(1):13-25.

26. Blumenthal S. From insulin and insulin-like activity to the insulin superfamily of growth-promoting peptides: a 20th-century odyssey. Perspect Biol Med. 2010;53(4):491-508.

27. Oh Y, Muller HL, Lamson G, Rosenfeld RG. Insulin-like growth factor (IGF)independent action of IGF-binding protein-3 in Hs578T human breast cancer cells. Cell surface binding and growth inhibition. J Biol Chem. 1993; 268(20):14964-71.

28. Imsumran A, Adachi Y, Yamamoto H, Li R, Wang Y, Min Y, Piao W, Nosho K, Arimura $Y$, Shinomura $Y$, et al. Insulin-like growth factor-I receptor as a marker for prognosis and a therapeutic target in human esophageal squamous cell carcinoma. Carcinogenesis. 2007;28(5):947-56.

29. Chen SC, Chou CK, Wong FH, Chang CM, Hu CP. Overexpression of epidermal growth factor and insulin-like growth factor-l receptors and autocrine stimulation in human esophageal carcinoma cells. Cancer Res. 1991;51(7):1898-903.

30. Liu YC, Leu CM, Wong FH, Fong WS, Chen SC, Chang C, Hu CP. Autocrine stimulation by insulin-like growth factor I is involved in the growth, tumorigenicity and chemoresistance of human esophageal carcinoma cells. J Biomed Sci. 2002;9(6 Pt 2):665-74.

31. Cui H, Cruz-Correa M, Giardiello FM, Hutcheon DF, Kafonek DR, Brandenburg S, Wu Y, He X, Powe NR, Feinberg AP. Loss of IGF2 imprinting: a potential marker of colorectal cancer risk. Science. 2003;299(5613):1753-5.

32. Di Martino E, Wild CP, Rotimi O, Darnton JS, Olliver RJ, Hardie LJ. IGFBP-3 and IGFBP-10 (CYR61) up-regulation during the development of Barrett's oesophagus and associated oesophageal adenocarcinoma: potential biomarkers of disease risk. Biomarkers. 2006;11(6):547-61.

33. Hu YC, Lam KY, Law S, Wong J, Srivastava G. Profiling of differentially expressed cancer-related genes in esophageal squamous cell carcinoma (ESCC) using human cancer CDNA arrays: overexpression of oncogene MET correlates with tumor differentiation in ESCC. Clin Cancer Res. 2001;7(11):3519-25.

34. Kashyap MK, Marimuthu A, Kishore CJ, Peri S, Keerthikumar S, Prasad TS, Mahmood R, Rao S, Ranganathan P, Sanjeeviah RC, et al. Genomewide mRNA profiling of esophageal squamous cell carcinoma for identification of cancer biomarkers. Cancer Biol Ther. 2009;8(1):36-46.

35. Takaoka M, Harada H, Andl CD, Oyama K, Naomoto Y, Dempsey KL, KleinSzanto AJ, El-Deiry WS, Grimberg A, Nakagawa H. Epidermal growth factor receptor regulates aberrant expression of insulin-like growth factor-binding protein 3. Cancer Res. 2004;64(21):7711-23.

36. Baxter RC. IGF binding proteins in cancer: mechanistic and clinical insights. Nat Rev Cancer. 2014;14(5):329-41.

37. Csibi A, Lee G, Yoon SO, Tong H, Ilter D, Elia I, Fendt SM, Roberts TM, Blenis J. The mTORC1/S6K1 pathway regulates glutamine metabolism through the elF4B-dependent control of c-Myc translation. Curr Biol. 2014;24(19):2274-80.

38. West MJ, Stoneley M, Willis AE. Translational induction of the c-myc oncogene via activation of the FRAP/TOR signalling pathway. Oncogene. 1998;17(6):769-80.

39. Hoxhaj G, Manning BD. The PI3K-AKT network at the interface of oncogenic signalling and cancer metabolism; 2019.

\section{Publisher's Note}

Springer Nature remains neutral with regard to jurisdictional claims in published maps and institutional affiliations.
Ready to submit your research? Choose BMC and benefit from:

- fast, convenient online submission

- thorough peer review by experienced researchers in your field

- rapid publication on acceptance

- support for research data, including large and complex data types

- gold Open Access which fosters wider collaboration and increased citations

- maximum visibility for your research: over $100 \mathrm{M}$ website views per year

At $\mathrm{BMC}$, research is always in progress.

Learn more biomedcentral.com/submissions 